\title{
DISTRIBUTION OF SMALL MAMMALS (EULIPOTYPHLA, RODENTIA) IN THE GRADIENT DIRECTION URBAN-SUBURBAN-RURAL OF CENTRAL SLOVAKIA
}

\author{
VLADIMÍR LANGRAF $\bigotimes^{1}$, ZUZANA KRUMPÁLOVÁ ${ }^{2}$, KORNÉLIA PETROVIČOVÁ ${ }^{4}$, ZUZANA POLÁČIKOVÁ \\ MICHAL AMBROS 3 , JANKA SCHLARMANNOVÁ ${ }^{2}$ \\ ${ }^{1}$ Department of Zoology and Anthropology, Faculty of Natural Sciences, Constantine the Philosopher University in Nitra, Tr. A. Hlinku 1, Nitra, Slovak Re- \\ public; langrafvladimir@gmail.com, zpolacikova@ukf.sk, jschlarmannova@ukf.sk \\ ${ }^{2}$ Department of Ecology and Environmental Sciences, Faculty of Natural Sciences, Constantine the Philosopher University in Nitra, Tr. A. Hlinku 1, Nitra, \\ Slovak Republic; zkrumpalova@ukf.sk \\ ${ }^{3}$ State Nature Protection of the Slovak Republic, Administration of the Protected Landscape Area of Ponitrie, Samova 3, 94901 Nitra, Slovak Republic; michal. \\ ambros@sopsr.sk \\ ${ }^{4}$ Department of Environment and Zoology, Faculty of Agrobiology and Food Resources Slovak University of Agriculture in Nitra, Tr. A. Hlinku 2 , 94976 \\ Nitra, Slovak Republic; kornelia.petrovicova@gmail.com
}

$\bowtie$ Corresponding author

Received: 29 November 2020 / Accepted: 7 February 2021

Abstract

Langraf V., Krumpálová Z., Petrovičová K., Poláčiková Z., Ambros M., Schlarmannová J.: Distribution of small mammals (Eulipotyphla, Rodentia) in the gradient direction urban-suburban-rural of central Slovakia. Ekológia (Bratislava), Vol. 40, No. 2, p. 145-153, 2021.

Changes in the structure of small mammals' communities (Eulipotyphla, Rodentia) along urban-rural gradient indicate the environmental state of stability or instability. Since small mammals are important with regard to the transmission of diseases to man and domestic animals, therefore knowledge of their association with the landscape structure is needed in land use planning. In course of the period from 2015 to 2017, there were recorded 109 individuals belonging to 15 species at 9 study sites ( 3 rural, 3 suburban, and 3 urban). We recorded a decrease in the average number of species in the direction of the suburban-urban-rural gradient. The number of individuals decreased in the rural-urban-suburban gradient. Eudominant species Clethrionomys glareolus $(\mathrm{D}=20.2 \%)$, Microtus arvalis $(13.8 \%)$, and Sorex araneus $(19.3 \%)$ preferred the close links between the terms of the rural landscape, while Apodemus agrarius $(\mathrm{D}=11.9 \%)$ and Sorex minutus $(\mathrm{D}=11.0 \%)$ preferred the close links between the terms of the urban landscape.

Key words: small mammals, urban environment, pitfall traps, Slovakia.

\section{Introduction}

The spatial distribution of animals is important for assessing the potential impacts of environmental changes. Specific reactions of species communities and the presence of asymmetry of morphometric features in the population are related to the characteristics of the urban landscape and changes in the environment (Shigesada, 1980; Saito, Koike, 2013). Human development is changing the landscape in many ways that affect the distribution of wild species of mammals. Urban ecosystems differ from natural ecosystems in warmer condition (microclimate), increased run off (hydrology), and higher concentrations of heavy metals (soil) (Alberti, 2005; Jančová, Baláž, 2004; Baláž, Jančová, 2005; Jančová et al., 2006; Korénková et al., 2006; Baláž, Ambros, 2005, 2012; Baláž, 2010; Baláž, Zigová, 2020). The increasing urbanization causing a shift in species composition from specialist to generalist (Alberti, Marzluff, 2004), and the composition of species is homogenized (Riem et al., 2012). Spatial modeling of small mammals has dealt with (Vaniscottea et al., 2009) and demonstrated the suitability of reducing the effect of extrapolation to map the distribution and clarify ecological processes. Currently, research on small mammals focuses on the impact of urbanization and urban fauna in America (Gardner-Santana et al., 2009; Munshi-South, Kharchenko, 2010), Asia (Hirota et al., 2004), and Europe (Baker et al., 2003). Also in the surrounding states of Slovakia, it was the work of Frynta et al. (1994) and Pelikán et al. (1983) for the Czech Republic. In Poland, small mammals were studied by Gliwicz (1981), Gortat et al. (2014, 2017), Haitlinger, (1962), and Jasińska, Goszczyński (2011). The diversity of small mammal communities and of the abundance are affected by human alterations, particularly urbanization (Klimant et al., 2015). These search results confirm the negative feed species Apodemus sylvaticus and Crocidura russula in the urban landscape. In contrast, Mus musculus is usually associated with the human 
presence and attachment to the urban landscape. The influence of the urban environment on the structure and occurrence of small mammals in the direction of the urban-rural gradient was pointed out (Klimant et al., 2017; Baker et al., 2003). They have found an increase in species richness in suburban conditions and a decrease in the urban environment. They have defined exoanthropic species Apodemus sylvaticus, A. flavicollis, Clethrionomys glareolus-avoiding man and his dwelling. Synanthropic species Crocidura suaveolens depend on human dwellings; hemisynanthropic species Microtus arvalis, Apodemus uralensis, Sorex araneus, S. minutus, and Mus spicilegus, Microtus subterraneus tend to the suburban landscape. Decreased diversity with increasing urbanization has been recorded (Cavia et al., 2009); the results indicate a strong connection of the species Rattus rattus, $R$. norvegicus, and Mus musculus to the urban landscape. Dominant representation in natural habitats of the rural landscape was found in the species Oligoryzomys flavescens, Deltamys kempi, Calomys musculinus, and Cavia aperea. They have found a negative effect of cat predation pressure and biota fragmentation on small mammals in urban landscapes (Gomes et al., 2011), where they also have pointed to the reduction in the effect of fragmentation by creating gardens. Rodents are involved in the transmission of diseases to humans and animals. They also cause damage to food storage and buildings, so information about their distribution in the city is important (Battersby, Greenwood, 2004; Morello et al., 2000). Urban ecosystems have fewer opportunities for ecological services aimed at regulating populations of small mammals to prevent their overgrowth (Clergeau et al., 2001). Knowledge of the associations of species with the landscape structure can also help in urban planning and improve the environmental conditions of the city for the native fauna (Garden et al., 2006; Fuente,1992).

Small mammals may be valuable indicators of habitat quality and may shape successional dynamics and even future composi- tion of vegetation structure. The distribution and abundance of small mammals are affected by the available resources, the evolutionary history, the degree of specialization, as well as the interactions between species (Pelikán et al., 1977). Small mammals are detected by trapping in trap types and in various sizes, using the linear and square methods (Kogut, Padley, 1997). Pitfall traps are very effective for catching small species of small mammals (especially representatives of the Eulipotyphla), which at the same time are difficult to catch in metal live traps due to their low body weight (Pankakoski, 1979; Stanko et al., 1999). They have been studied by comparing the selective effects of three types of traps (ground, animal, and tipping) (Ambros, Gajdoš, 1988; Ambros et al., 2010; Dudich, Štollmann 1985). Larger volume pitfall traps are used to make small mammals more successful (Dudich et al., 1987).

The aim of this study is to determine the dispersion analysis of Eulipotyphla and Rodentia during the years 2015-2017 in the direction of the urban-suburban gradient in the conditions of Central Europe. The results of the research are useful in planning decisions on pest control based on the composition of rodent communities derived from the landscape structure.

\section{Material and methods}

The research of small mammals took place from 2015 to 2017, during the months of April-November in nine study sites and seven types of biotopes. Materials from pitfall traps were collected at regular biweekly intervals. We used pitfall traps (volume: $750 \mathrm{ml}$; Novák et al., 1969). Five pitfall traps were arranged in the line per each locality at a distance of $10 \mathrm{~m}$ away from each other. A total of 45 pitfall traps were used. We have used formaldehyde as a preservative solution. We have identified collected material, and the nomenclature according to Gaisler et al. (1962) and Baláž et al. (2013) was used.

Table 1. Location data of the study localities.

\begin{tabular}{|c|c|c|c|c|c|c|}
\hline Geomorphological unit & Study area & C. a. & m a.s.l. & Landscape & Biotope & G.C. \\
\hline \multirow{3}{*}{$\begin{array}{l}\text { Stolické vrchy } \\
\text { hills }\end{array}$} & 1 Lichovo & Utekáč & 518 & Rural & Culture of Picea abies & $\begin{array}{l}48^{\circ} 36^{\prime} 27^{\prime \prime} \mathrm{S} \\
19^{\circ} 48^{\prime} 23^{\prime \prime} \mathrm{V}\end{array}$ \\
\hline & 2 Lichovo & Utekáč & 556 & Rural & Meadow & $\begin{array}{l}48^{\circ} 36^{\prime} 30^{\prime \prime} \mathrm{S} \\
19^{\circ} 48^{\prime} 35^{\prime \prime} \mathrm{V}\end{array}$ \\
\hline & 3 Farkaška & Utekáč & 446 & Rural & Nitrophilous waterside vegetation & $\begin{array}{l}48^{\circ} 36^{\prime} 34^{\prime \prime} \mathrm{S} \\
19^{\circ} 47^{\prime} 52^{\prime \prime} \mathrm{V}\end{array}$ \\
\hline \multirow{6}{*}{$\begin{array}{l}\text { Juhoslovenská kotlina } \\
\text { basin }\end{array}$} & 4 Kúpna hora & Poltár & 300 & Suburban & Carpathian oak-hornbeam forest & $\begin{array}{l}48^{\circ} 26^{\prime} 09^{\prime \prime} \mathrm{S} \\
19^{\circ} 49^{\prime} 27^{\prime \prime} \mathrm{V}\end{array}$ \\
\hline & 5 Prievranka & Poltár & 272 & Suburban & Pasture & $\begin{array}{l}48^{\circ} 25^{\prime} 52^{\prime \prime} \mathrm{S} \\
19^{\circ} 49^{\prime} 08^{\prime \prime} \mathrm{V}\end{array}$ \\
\hline & 6 Pažit & Poltár & 218 & Suburban & Nitrophilous waterside vegetation & $\begin{array}{l}48^{\circ} 25^{\prime} 41^{\prime \prime} \mathrm{S} \\
19^{\circ} 46^{\prime} 35^{\prime \prime} \mathrm{V}\end{array}$ \\
\hline & 7 pri Ladove & Lučenec & 258 & Urban & Carpathian turkey oak forest & $\begin{array}{l}48^{\circ} 19^{\prime} 08^{\prime \prime} \mathrm{S} \\
19^{\circ} 37^{\prime} 48^{\prime \prime} \mathrm{V}\end{array}$ \\
\hline & 8 Zajačie brehy & Lučenec & 208 & Urban & Fallow field & $\begin{array}{c}48^{\circ} 19^{\prime} 017^{\prime \prime} \mathrm{S} \\
19^{\circ} 39^{\prime} 05^{\prime \prime} \mathrm{V}\end{array}$ \\
\hline & 9 Ladovo & Lučenec & 207 & Urban & Nitrophilous waterside vegetation & $\begin{array}{l}48^{\circ} 20^{\prime} 12^{\prime \prime} \mathrm{S} \\
19^{\circ} 37^{\prime} 06^{\prime \prime} \mathrm{V}\end{array}$ \\
\hline
\end{tabular}

Notes: C. a. - cadastral area; m a.s.l. - meters above sea level; G.C. - geographic coordinates. 


\section{Study area}

The study areas are located in the southern part of Central Slovakia, geomorphological units Stolické vrchy hills, and Juhoslovenská kotlina basin (Table 1).

\section{Statistical analyses}

Spatial modeling was performed by multivariate analysis with which we look for dependencies between objects of the rural, suburban, urban landscapes, and species. We used principal component analysis (PCA) to evaluate the dependence between objects (Ter Braak, Šmilauer, 2012). The statistical program Statistica Cz. Ver. 7.0 Statistica Cz. Ver. 7.0 (StatSoft, Inc., 2004) using Shapiro-Wilk $W$ test, Kruskal-Wallis test (ANOVA), Friedman test (ANOVA), and Turkey's HSD test (post-hoc) was used. A significant difference in the number of individuals and species between 2015 and 2017 in the conditions of rural, suburban, or urban landscapes was recorded.

\section{Results}

In total, we have recorded 109 individuals belonging to 15 species in the studied areas. In rural conditions, we have obtained 46 individuals belonging to 8 species; eudominants were Sorex araneus (28\%), Clethrionomys glareolus (24\%), and Microtus arvalis (20\%). In the suburban area, we have captured 25 individuals belonging to 10 species; eudominants were Clethrionomys glareolus (28\%), Sorex araneus (16\%), and Neomys fodiens (12\%). In the urban area, we have obtained 38 individuals included in 11 species; Apodemus agrarius (21\%), Sorex minutus (18\%), Apodemus flavicollis (13\%), Microtus arvalis (13\%), and Sorex araneus (11\%) were eudominants (Table 2).
Spatial modeling of the distribution of small mammals of the studied areas (rural, subrurban, and urban) was determined by PCA ( $\mathrm{SD}=1.1$ was on the first ordination axis). The values of the explained cumulative variability of species data were $68.7 \%$ on the first ordination axis and $98.09 \%$ on the second ordination axis. The ordination graph of material analysis (biplot) (Fig. 1) includes the species ordered into three clusters. The first cluster consists of species preferring the rural landscape, namely Neomys anomalus, Sorex araneus, Clethrionomys glareolus, and Microtus arvalis. The second cluster was created by the species Apodemus uralensis, Microtus agrestis, and Neomys fodiens correlating to the suburban landscape. The third cluster was represented by Apodemus agrarius, Cricetus cricetus, Micromys minutus, Microtus subterraneus, and Sorex minutus preferring urban landscape. Apodemus flavicollis and Crocidura suaveolens are located between clusters II and III, indicating a preference for suburban and urban landscapes. Muscardinus avellanarius was placed between clusters I and III, thus pointing to the connection of the species to the rural and urban landscapes.

The normality data distribution number of individuals was tested by Shapiro-Willk W test during the years 2015-2017 (P value $=0.000)$. Based on the violation of the normality of the data distribution, we used a nonparametric Kruskal-Wallis test (ANOVA) to confirm the statistically significant difference (Pvalue $=0.047)($ Fig. 2) of individuals between rural, suburban, and urban landscapes. From the results, we have seen a decrease in the number of individuals in the direction of the rural-urbansuburban gradient.

Based on the violation of the normality of the data distribution, we used a nonparametric Friedman test (ANOVA) to confirm the statistically significant difference $(\mathrm{P}$-value $=0.022)$ (Fig. 3) of individuals during the year 2015-2017 between rural, suburban, and urban landscapes. Using a post-hoc test (Tur-

Table 2. Distribution of the Eulipotyphla and Rodentia in the study sites.

\begin{tabular}{|l|c|c|c|c|c|c|c|c|}
\hline \multirow{2}{*}{ Species } & \multicolumn{2}{c|}{ Rural } & \multicolumn{2}{c|}{ Suburban } & \multicolumn{2}{c|}{ Urban } & $\boldsymbol{\Sigma}$ ind. & D (\%) \\
\cline { 2 - 9 } & ind. & $\mathbf{D}(\%)$ & ind. & $\boldsymbol{D}(\%)$ & ind. & $\boldsymbol{D}(\%)$ & & \\
\hline Apodemus agrarius (Pallas, 1771) & 4 & $8.70 \%$ & 1 & $4.00 \%$ & 8 & $21.05 \%$ & 13 & $11.93 \%$ \\
\hline Apodemus flavicollis (Melchior, 1834) & - & $0.00 \%$ & 4 & $16.00 \%$ & 5 & $13.16 \%$ & 9 & $8.26 \%$ \\
\hline Apodemus uralensis (Pallas, 1811) & - & $0.00 \%$ & 1 & $4.00 \%$ & - & $0.00 \%$ & 1 & $0.92 \%$ \\
\hline Clethrionomys glareolus (Schreber, 1780) & 11 & $23.91 \%$ & 7 & $28.00 \%$ & 4 & $10.53 \%$ & 22 & $20.18 \%$ \\
\hline Cricetus cricetus (Linnaeus, 1758) & - & $0.00 \%$ & - & $0.00 \%$ & 1 & $2.63 \%$ & 1 & $0.92 \%$ \\
\hline Crocidura suaveolens (Pallas, 1811) & - & $0.00 \%$ & 1 & $4.00 \%$ & 1 & $2.63 \%$ & 2 & $1.83 \%$ \\
\hline Micromys minutus (Pallas, 1771) & - & $0.00 \%$ & - & $0.00 \%$ & 1 & $2.63 \%$ & 1 & $0.92 \%$ \\
\hline Microtus agrestis (Linnaeus, 1761) & - & $0.00 \%$ & 1 & $4.00 \%$ & - & $0.00 \%$ & 1 & $0.92 \%$ \\
\hline Microtus arvalis (Pallas, 1778) & 9 & $19.57 \%$ & 1 & $4.00 \%$ & 5 & $13.16 \%$ & 15 & $13.76 \%$ \\
\hline $\begin{array}{l}\text { Microtus subterraneus (de Sélys Longchamps, } \\
\text { 1836) }\end{array}$ & - & $0.00 \%$ & - & $0.00 \%$ & 1 & $2.63 \%$ & 1 & $0.92 \%$ \\
\hline Muscardinus avellanarius (Linnaeus, 1758) & 1 & $2.17 \%$ & - & $0.00 \%$ & 1 & $2.63 \%$ & 2 & $1.83 \%$ \\
\hline Neomys anomalus (Cabrera, 1907) & 4 & $8.70 \%$ & - & $0.00 \%$ & - & $0.00 \%$ & 4 & $3.67 \%$ \\
\hline Neomys fodiens (Pennant, 1771) & 1 & $2.17 \%$ & 3 & $12.00 \%$ & - & $0.00 \%$ & 4 & $3.67 \%$ \\
\hline Sorex araneus Linnaeus, 1758 & 13 & $28.26 \%$ & 4 & $16.00 \%$ & 4 & $10.53 \%$ & 21 & $19.27 \%$ \\
\hline Sorex minutus Linnaeus, 1766 & 3 & $6.52 \%$ & 2 & $8.00 \%$ & 7 & $18.42 \%$ & 12 & $11.01 \%$ \\
\hline I individuals & 46 & $100 \%$ & 25 & $100 \%$ & 38 & $100 \%$ & 109 & $100 \%$ \\
\hline
\end{tabular}

Note: ind. - individuals. 


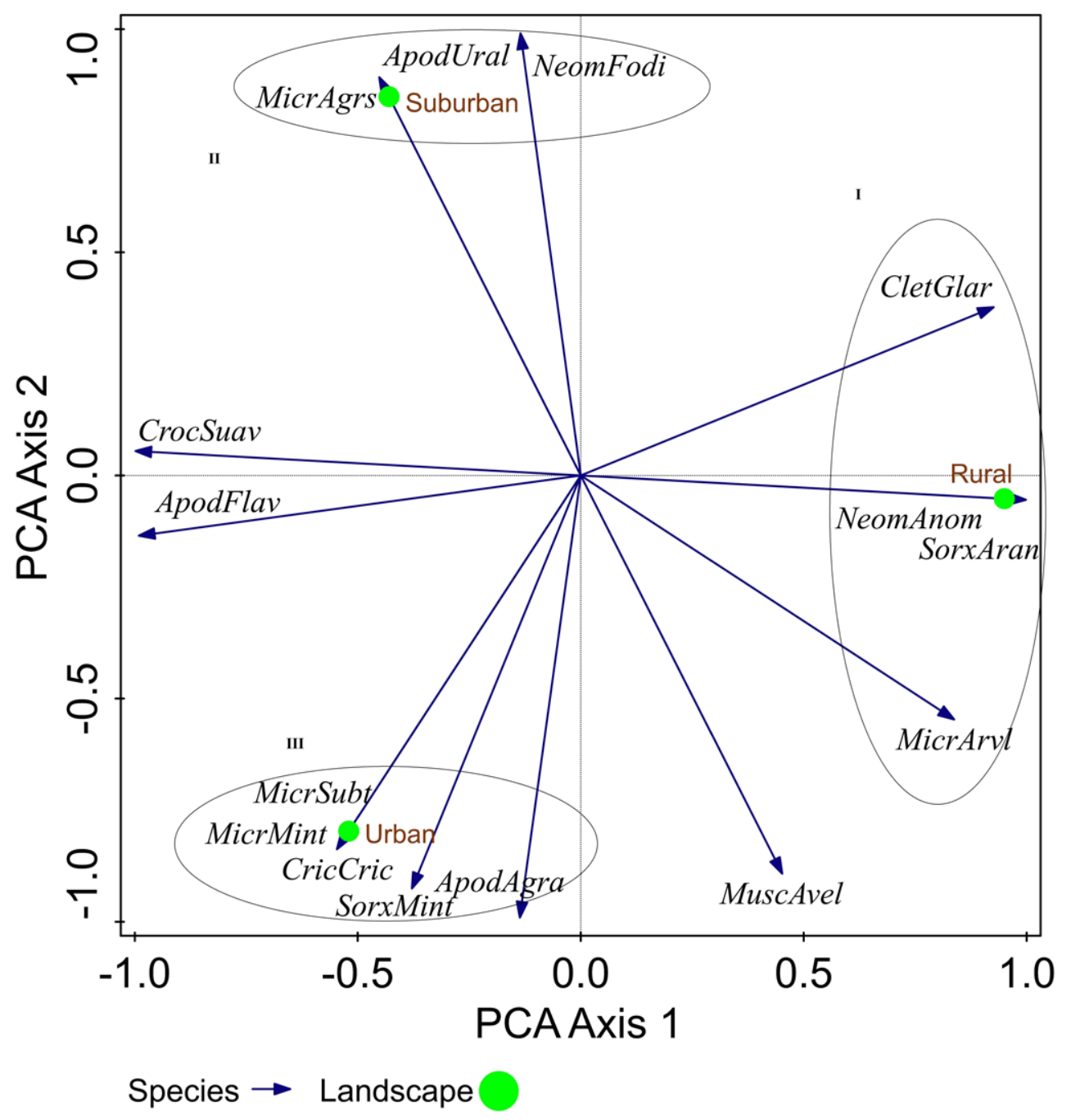

Fig. 1. PCA analysis of species distribution in the gradient urban-suburban-rural landscape.

key's HSD), we have identified which landscapes (rural, suburban, and urban) differed between 2015 and 2017 at the level of statistical significance pa $=0.05$ (Table 3). From the results, we have seen a decrease in the average value of individuals in rural conditions for 2016 and a subsequent increase for 2017. In the suburban landscape, we have found a decrease between 2016 and 2017. Urban landscape has decreased in 2016 and maintained a similar average value for 2017.

Table 3. Results of post-hoc test.

\begin{tabular}{|c|c|c|c|c|c|c|c|c|c|}
\hline Combinations & $\mathbf{1}$ & $\mathbf{2}$ & $\mathbf{3}$ & $\mathbf{4}$ & $\mathbf{5}$ & $\mathbf{6}$ & $\mathbf{7}$ & $\mathbf{8}$ & $\mathbf{9}$ \\
\hline $\mathbf{1}$ & - & 0.025 & 0.550 & 0.021 & 0.067 & 0.024 & 0.157 & 0.041 & 0.071 \\
\hline $\mathbf{2}$ & 0.025 & - & 0.011 & 0.688 & 0.682 & 0.849 & 0.240 & 0.837 & 0.501 \\
\hline $\mathbf{3}$ & 0.550 & 0.011 & - & 0.009 & 0.029 & 0.011 & 0.064 & 0.018 & 0.029 \\
\hline $\mathbf{4}$ & 0.021 & 0.688 & 0.009 & - & 0.936 & 0.563 & 0.323 & 0.872 & 0.714 \\
\hline $\mathbf{5}$ & 0.067 & 0.682 & 0.029 & 0.936 & - & 0.570 & 0.479 & 0.837 & 0.822 \\
\hline $\mathbf{6}$ & 0.024 & 0.849 & 0.011 & 0.563 & 0.570 & - & 0.203 & 0.704 & 0.414 \\
\hline $\mathbf{7}$ & 0.157 & 0.240 & 0.064 & 0.323 & 0.479 & 0.203 & - & 0.346 & 0.592 \\
\hline $\mathbf{8}$ & 0.041 & 0.837 & 0.018 & 0.872 & 0.837 & 0.704 & 0.346 & - & 0.653 \\
\hline $\mathbf{9}$ & 0.071 & 0.501 & 0.029 & 0.714 & 0.822 & 0.414 & 0.592 & 0.653 & - \\
\hline
\end{tabular}

Notes: 1 - rural in the year 2015; 2 - rural in the year 2016; 3 - rural in the year 2017; 4 - suburban in the year 2015; 5 - suburban in the year 2016; 6 - suburban in the year 2017; 7 - urban in the year 2015; 8 - urban in the year 2016; 9 - urban in the year 2017. 


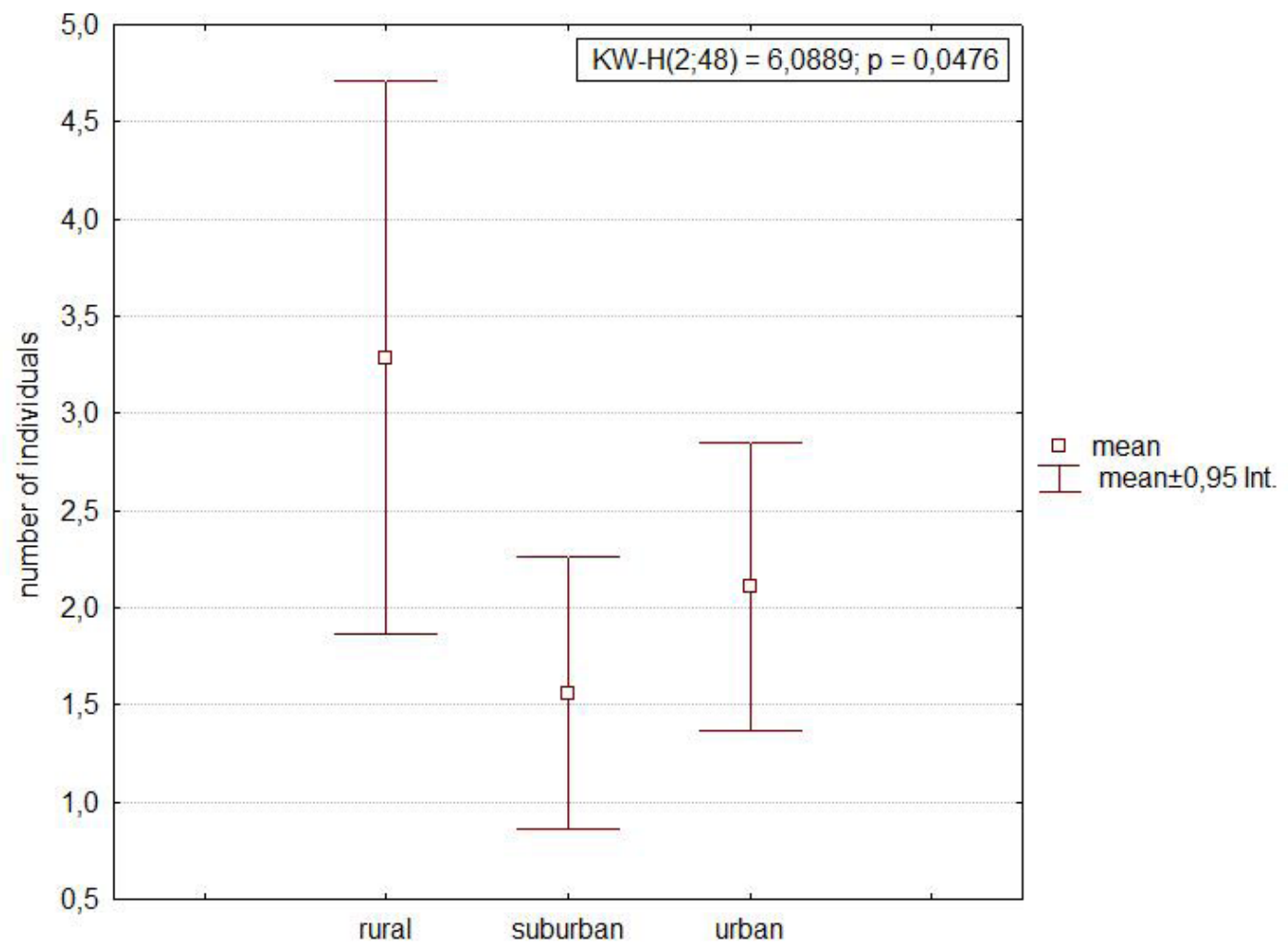

Fig. 2. Kruskal-Wallis test (ANOVA) to calculate the difference of number of individuals.

$F(4,39)=1,4767, p=0,02289$

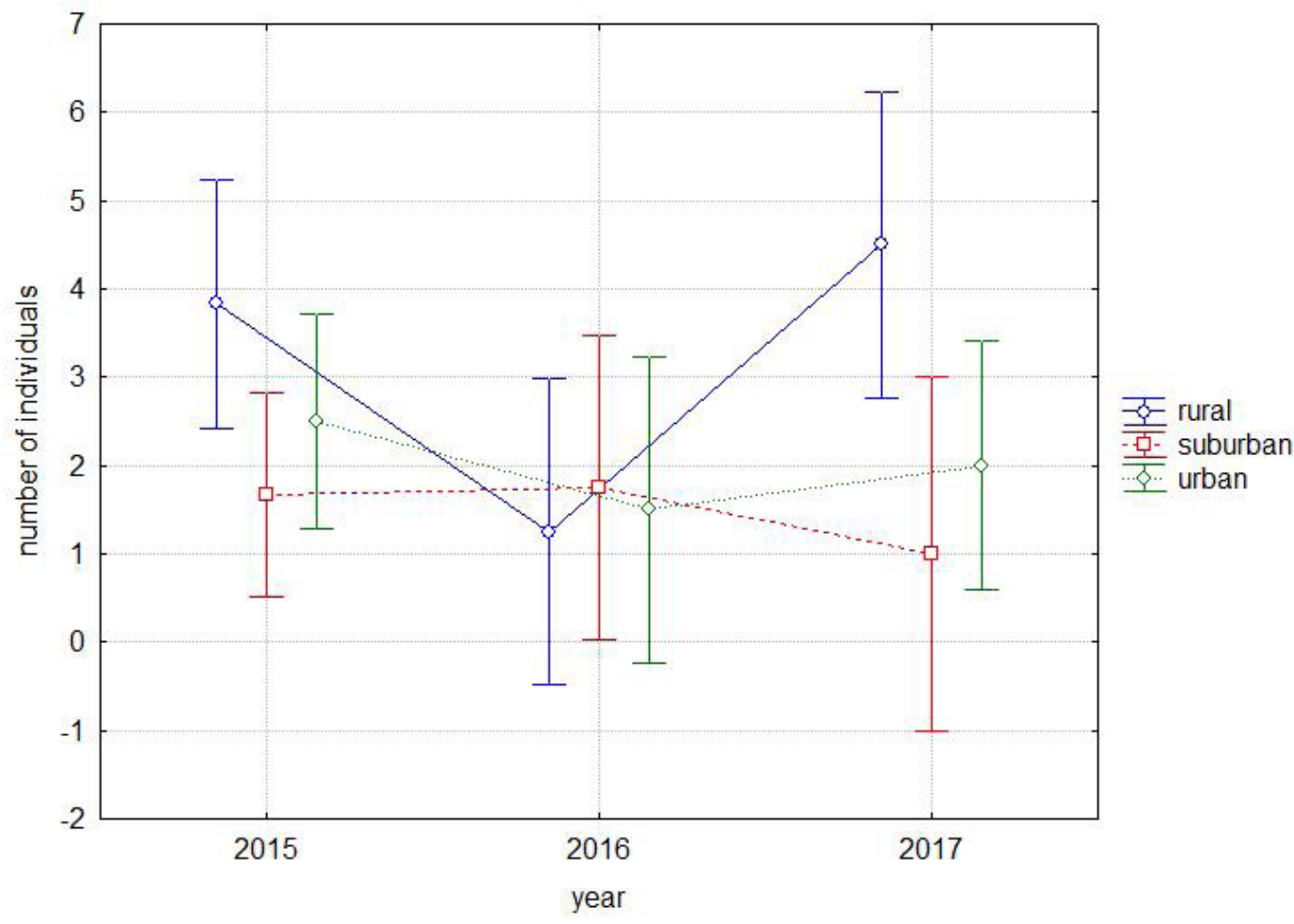

Fig. 3. Analysis of variance (Friedman test (ANOVA)) of the average number of individuals' values. 
Ekológia (Bratislava) 2021: 40(2): 145-153

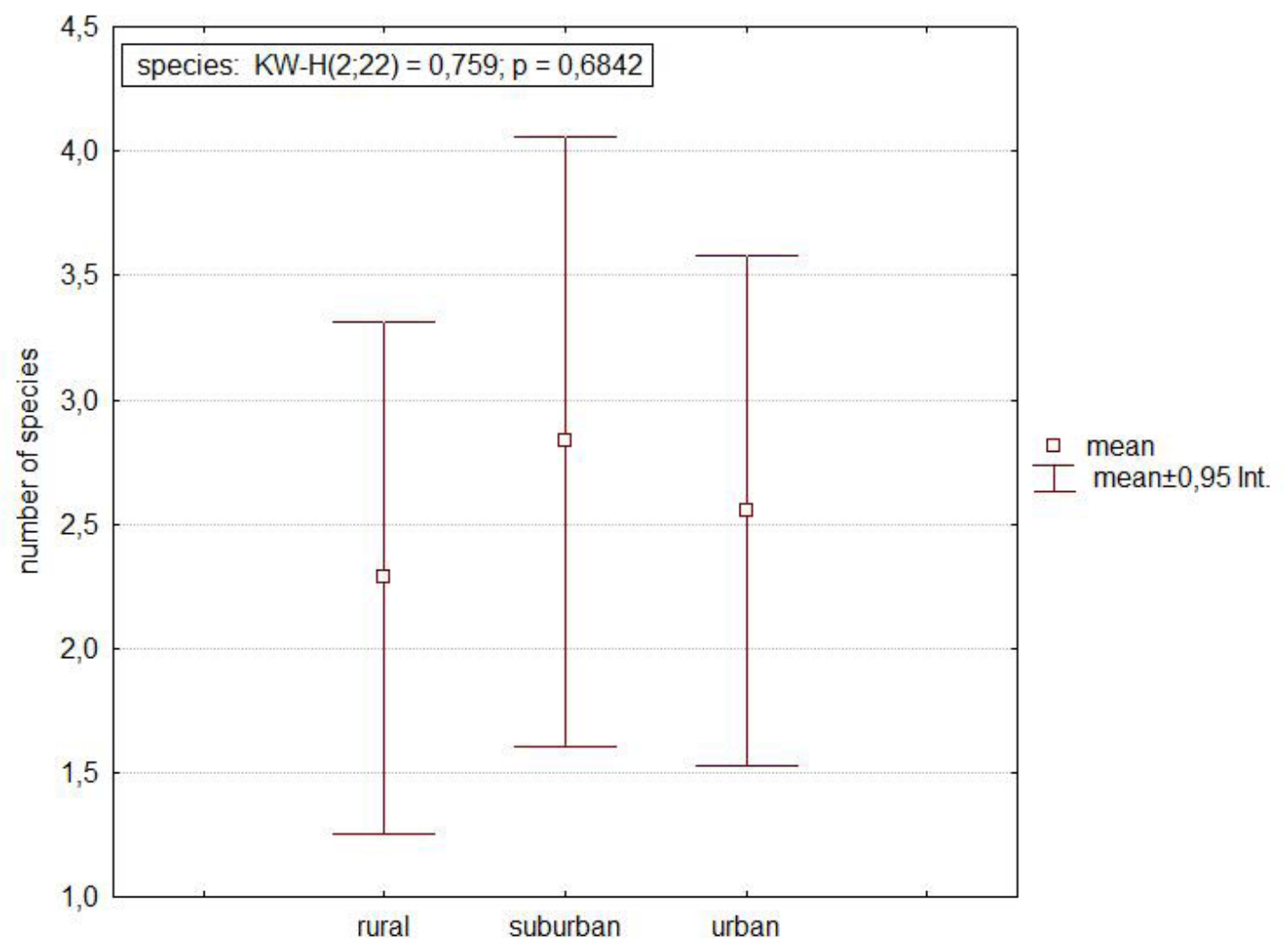

Fig. 4. Kruskal-Wallis test (ANOVA) to calculate the difference of number of species.

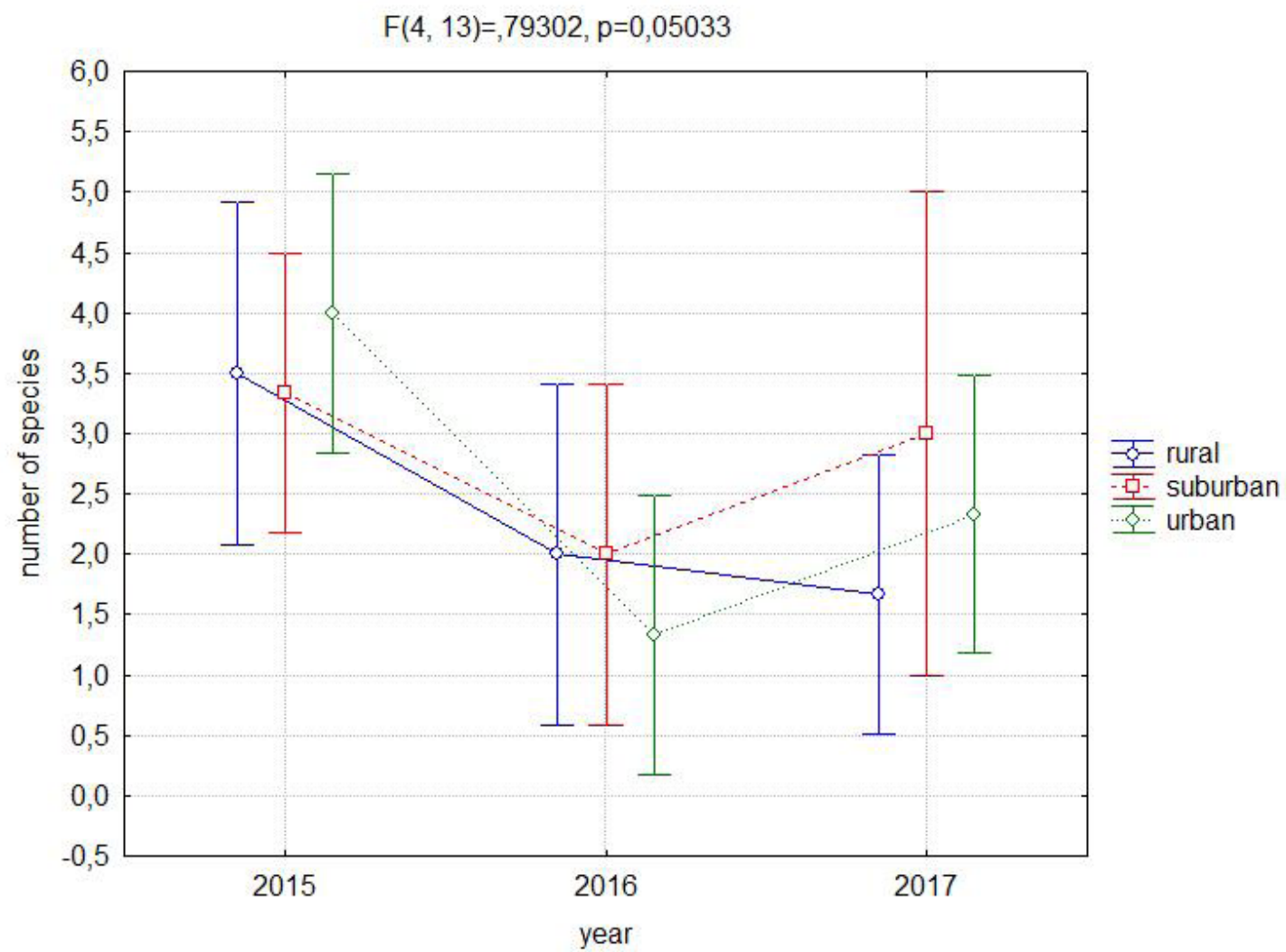

Fig. 5. Analysis of variance (Friedman test (ANOVA)) of average number of species values. 
Table 4. Results of post-hoc test.

\begin{tabular}{|c|c|c|c|c|c|c|c|c|c|}
\hline Combinations & $\mathbf{1}$ & $\mathbf{2}$ & $\mathbf{3}$ & $\mathbf{4}$ & $\mathbf{5}$ & $\mathbf{6}$ & $\mathbf{7}$ & $\mathbf{8}$ & $\mathbf{9}$ \\
\hline $\mathbf{1}$ & - & 0.130 & 0.049 & 0.847 & 0.130 & 0.667 & 0.565 & 0.024 & 0.191 \\
\hline $\mathbf{2}$ & 0.130 & - & 0.700 & 0.139 & 1.000 & 0.394 & 0.034 & 0.445 & 0.700 \\
\hline $\mathbf{3}$ & 0.049 & 0.700 & - & 0.046 & 0.700 & 0.235 & 0.009 & 0.667 & 0.394 \\
\hline $\mathbf{4}$ & 0.847 & 0.139 & 0.046 & - & 0.139 & 0.760 & 0.394 & 0.020 & 0.209 \\
\hline $\mathbf{5}$ & 0.130 & 1.000 & 0.700 & 0.139 & - & 0.394 & 0.034 & 0.445 & 0.700 \\
\hline $\mathbf{6}$ & 0.667 & 0.394 & 0.235 & 0.760 & 0.394 & - & 0.367 & 0.143 & 0.544 \\
\hline $\mathbf{7}$ & 0.565 & 0.034 & 0.009 & 0.394 & 0.034 & 0.367 & - & 0.004 & 0.046 \\
\hline $\mathbf{8}$ & 0.024 & 0.445 & 0.667 & 0.020 & 0.445 & 0.143 & 0.004 & - & 0.209 \\
\hline $\mathbf{9}$ & 0.191 & 0.700 & 0.394 & 0.209 & 0.700 & 0.544 & 0.046 & 0.209 & - \\
\hline
\end{tabular}

Notes: 1 - rural in the year 2015; 2 - rural in the year 2016; 3 - rural in the year 2017; 4 - suburban in the year 2015; 5 - suburban in the year 2016; 6 - suburban in the year 2017; 7 - urban in the year 2015; 8 - urban in the year 2016; 9 - urban in the year 2017.

The normality data distribution number of species was tested by Shapiro-Willk W test during the years 2015-2017 (P value $=$ 0.047). Based on the violation of the normality of the data distribution, we used a nonparametric Kruskal-Wallis test (ANOVA) to confirm the statistically nonsignificant difference (P-value = 0.684) (Fig. 4) of species between rural, suburban, and urban landscapes. We have observed a decrease in the number of species in the direction of the suburban-urban-rural gradient.

Based on the violation of the normality of the data distribution, we have used a nonparametric Friedman test (ANOVA) to confirm the statistically significant difference $(\mathrm{P}$-value $=0.050)$ (Fig. 5) of species during the year 2015-2017 between the rural, suburban, and urban landscapes. Using a post-hoc test (Turkey's HSD), we have identified which landscapes (rural, suburban, and urban) differed between 2015 and 2017 at the level of statistical significance $\mathrm{pa}=0.05$ (Table 4 ). We have presented the downward random phenomena in the average value of species during the period 2015-2017 in rural conditions among all the years 2015-2017. We have found a decrease for the year 2016 and then an increase in 2017 in terms of the suburban and urban landscapes.

\section{Discussion}

The highest number of species during the research years 2015-2017 was recorded in the urban landscape and the lowest in the rural landscape but with the highest number of individuals. The lowest number of individuals was found in the suburban landscape. The spread of wildlife to the urban environment due to human activity associated with land change has been confirmed by (Alberti, 2005; Jančová, Baláž, 2004; Baláž, Jančová, 2005; Jančová et al., 2006; Baláž, Ambros, 2005, 2012; Kalivoda et al., 2010; Baláž, Zigová, 2020). The eudominant species of our results are Apodemus agrarius, Clethrionomys glareolus, Microtus arvalis (family Muridae), and Sorex araneus, S. minutus (family Soricidae). The more successful capture of species from the family Soricidae in pitfall traps has also been recorded (Ambros et al., 2010; Dudich, Štollmann, 1985). The great success of catching species of the family Muridae into pitfall traps with a larger volume was found in the work of Dudich et al. (1987). A more complex coenose of small mammals using pitfall traps was confirmed (Pankakoski, 1979; Stanko et al., 1999; Ambros, Gajdoš, 1988), as the reason for effective capture was given by the small bodyweight of small mammals. The suitability of the linear method of trapping as we have observed in our research has been also described by other authors (Kogut, Padley 1997).

By spatial modeling of small mammals, we have confirmed the connection of species Neomys anomalus, Sorex araneus, Clethrionomys glareolus, and Microtus arvalis to the rural landscape conditions. The species Apodemus uralensis, Microtus agrestis, and Neomys fodiens prefer conditions of the suburban landscape. We have found a correlation in the urban landscape in the species Apodemus agrarius, Cricetus cricetus, Micromy sminutus, Microtus subterraneus, and Sorex minutus. The species Apodemus flavicollis and Crocidura suaveolens showed a link to the urban and suburban landscapes, while Muscardinus avellanarius, in addition to the urban environment, also linked to breeding conditions. They have also defined a similar link (Klimant et al., 2015, 2017; Baker et al., 2003; Cavia et al., 2009; Frynta et al., 1994; Pelikán et al., 1983; Gliwicz, 1981; Gortat et al., 2017; Haitlinger, 1962; Jasińska, Goszczyński, 2011), where they have divided the species into synanthropic species, which included Crocidura suaveolens with a connection to the urban environment as in our results. Among exoanthropic species with a connection to the rural landscape, we have obtained one identical species Clethrionomys glareolus. Hemisynanthropic species correlated with conditions of the suburban landscape; we have found one identical species, Apodemus uralensis. The suitability of the use of spatial modeling for the assessment of communities in the impact of environmental change has also been pointed out (Shigesada, 1980; Saito, Koike, 2013; Vaniscottea et al., 2009).

The Kruskal-Wallis test (ANOVA) has confirmed a decrease in the number of individuals in the direction of the rural-urban-suburban gradient and a decrease in the species in the direction of the suburban-urban-rural direction. They have found a shift in species, a change in species composition, and their abundance due to urbanization (Alberti, Marzluff, 2004; Riem et al., 2012). The same results in the urban environment have been confirmed in America (Gardner-Santana et al., 2009; MunshiSouth, Kharchenko, 2010), Asia (Hirota et al., 2004), and Europe (Baker et al., 2003; Gortat et al., 2014). We have found a decrease in the average value of species in year-on-year intervals in the rural landscape, while the number of individuals increased during 2017. The decrease in species in 2016 and the subsequent in- 
crease were confirmed in the suburban and urban landscapes. The number of individuals has decreased in suburban conditions during 2017; for the urban landscape, there was a decrease to 2016 with a subsequent random phenomenon in 2017.

The distribution of small mammals is affected not only by the availability of resources but also by the interaction between species (Pelikán et al., 1977). Information of the species association with the landscape structure will improve the planning of urban environmental conditions (Garden et al., 2006; Fuente, 1992) to improve ecological services to prevent overpopulation (Clergeau et al., 2001). By preventing overgrowth, the transmission of diseases to humans and animals, respectively, damaged to stored foods (Battersby, Greenwood, 2004; Morello et al., 2000).

\section{Conclusion}

We have confirmed the decrease in the average value of species during the years 2015- 2017 in rural conditions, but the number of individuals increased during 2017. In suburban and urban areas, the decrease in the number of species during 2016 and the subsequent increase in 2017 were confirmed. The number of individuals has decreased in 2017 in suburban and urban conditions in 2016, maintaining a similar value for 2017. The overall decrease in the average number of species during the years 2015-2017 was in the direction of the suburban-urban-rural gradient and the number of individuals in the rural-urban-suburban direction. We have found the association of eudominant species Clethrionomys glareolus $(D=20 \%)$, Microtus arvalis (14\%), and Sorex araneus (19\%) with the rural landscape conditions through spatial modeling. Apodemus agrarius $(D=12 \%)$ and Sorex minutus $(D=11 \%)$ correlated with the urban landscape.

The results of the study are applicable to the creation of spatial planning documents for the development of environmental systems in the urban landscape, which we will deal with in future studies.

\section{Acknowledgements}

This research was supported by the project VEGA 1/0604/20 Environmental assessment of specific habitats in the Danube Plain. KEGA No. 019UKF-4/2021 Creation and innovation of education - Zoology for Ecologists, part - Invertebrates.

\section{References}

Alberti, M. (2005). The effects of urban patterns on ecosystem function. International Regional Science Review, 28, 168-192. DOI: $10.1177 / 0160017605275160$.

Alberti, M. \& Marzluff J.M. (2004). Ecological resilience in urban ecosystems: linking urban patterns to human and ecological functions. Urban Ecosystems, 7, 241-265. DOI: 10.1023/B:UECO.0000044038.90173.c6.

Ambros, M., Baláž, I. \& Gajdoš P. (2010). Small mammals (Rodentia, Eulipotyphla) of the oak-hornbeam forest Báb near Nitra (Nitranská pahorkatina - hilly land) (in Slovak). Rosalia, 21, 185-193.

Ambros, M. \& Gajdoš P. (1988). The occurence of some vertebrates (Amphibia, Reptilia, Mammalia) in samples obtainedd from palitraps on the territory of the Protected Landscape Area Ponitrie (in Slovak). Rosalia, 5, 177-188.

Baker, P.J., Ansell, R.J., Dodds, P.A.A., Webber, C.E. \& Harris S. (2003). Factors affecting the distribution of small mammals in an urban area. Mam mal Rev., 33, 95-100. DOI: 10.1046/j.1365-2907.2003.00003.x.
Baláž, I. \& Ambros M. (2005). Relationship of shrews (Sorex sp.) to forest biotopes in Western Carpathians. Ekológia (Bratislava), 24(3), 254-262. DOI: 10.2478 /eko-2020-0020.

Baláž, I. \& Jančová A. (2005). Small terrestrial mammals synusia changes during several days of continual trapping. Ekológia (Bratislava), 24(4), 337-343. DOI: 10.2478/eko-2020-0020.

Baláž, I. (2010). The influence of the altitude on somatic characteristics size of common vole (Microtus arvalis) in Slovakia. Ekológia (Bratislava), 29(2), 174-181. DOI: 10.2478/eko-2020-0020.

Baláž, I. \& Ambros M. (2012). Population analysis and spatial activity of Rodents in flooded forest conditions. Ekológia (Bratislava), 31(3), 249-263. DOI: 10.2478 /eko-2020-0020.

Baláž, I., Ambros, M., Tulis, F., Veselovský, T., Klimant, P. \& Augustiničová G. (2013). Rodents and insectivores of Slovakia (in Slovak). Nitra: UKF.

Baláž, I. \& Zigová M. (2020). Flea communities on small mammals in lowland environment. Ekológia (Bratislava), 39(3), 260-269. DOI: 10.2478/ eko-2020-0020.

Battersby, J.E. \& Greenwood J.J.D. (2004). Monitoring terrestrial mammals in the UK: past, present and future, using lessons from the bird world. Mammal Rev., 34, 3-29. DOI: 10.1046/j.0305-1838.2003.00023.x.

Cavia, R., Cuetoa, R.C. \& Suárez V. (2009). Changes in rodent communities according to the landscape structure in an urban ecosystem. Landsc. Urban Plann., 90, 11-19. DOI: 10.1016/j.landurbplan.2008.10.017.

Clergeau, P., Jokimäki, J. \& Savard J.-P.L. (2001). Are urban bird communities influenced by the bird diversity of adjacent landscapes? J. Appl. Ecol., 38, 1122-1134. DOI: 10.1046/j.1365-2664.2001.00666.x.

Dudich, A. \& Štollmann A. (1985). Pitfall traps and their effectiveness in terms of terrestrial micromamial fauna research. Biológia, 40, 1049-1054.

Dudich, A., Kleinert, J. \& Štollmann A. (1987). Occurrence of small terrestrial mammals in samples obtained by pitfall traps. Lynx, 23, 43-50.

Frynta, D., Vohralík, V. \& Rezníček J. (1994). Small mammals (Insectivora, Rodentia) in the city of Prague: distributional patterns. Acta Soc. Zool. Bohem., 58, 151-176.

Fuente, M.A. (1992). Distribucion y Preferencias de habitat de los Micromamiferos (Insectivora e Rodentia) de la Sierra de Guadarrama. Dissertation, Universidad Complutense de Madrid.

Gaisler, J., Holišová, V., Pelikán, J. \& Zejda J. (1962). The key to the identification of small mammals according to external signs (in Czech). Brno: ČSAV.

Garden, J., McAlpine, C., Peterson, A., Jones, D. \& Possingham H. (2006) Review of the ecology of Australian urban fauna: A focus on spatially explicit processes. Austral Ecol., 31, 126-148. DOI: 10.1111/j.14429993.2006.01578.x.

Gardner-Santana, L.C., Norris, D.E., Fornadel, C.M., Hinson, E.R., Klein, S.L. \& Glass G.E. (2009). Commensal ecology, urban landscapes, and their influence on the genetic characteristics of city-dwelling Norway rats (Rattus norvegicus). Mol. Ecol., 18, 2766-2778. DOI: 10.1111/j.1365294X.2009.04232.x.

Gliwicz, J. (1981). Competitive interactions within aforest rodent community in central Poland. Oikos, 37(3), 353-362. DOI: 10.2307/3544128.

Gomes, V., Ribeiro, R. \& Carretero M.A. (2011). Effects of urban habitat fragmentation on common small mammals: species versus communities. Biodivers. Conserv., 20, 3577-3590. DOI: 10.1007/s10531-011-0149-2.

Gortat, T., Barkowska, M., Rutkowski, R., Gryczynska-Siemią Tkowska, A., Pieniążek, A., Kozakiewicz, A. \& Kozakiewicz M. (2014). The effects of urbanization - small mammal communities in a gradient of human pressure in Warsaw city, Poland. Pol. J. Ecol., 62, 163-172. DOI: 10.3161/104.062.0115.

Gortat, T., Rutkowski, R., Gryczyńska, A., Kozakiewicz, A. \& Kozakiewicz M. (2017). The spatial genetic structure of the yellow-necked mouse in an urban environment - a recent invader vs. a closely related permanent inhabitant. Urban Ecosystems, 20(3), 581-594. DOI: 10.1007/s11252016-0620-7.

Haitlinger, R. (1962). Zmienność morfologiczna Apodemus agrarius (Pallas 1771). Acta Theriol., 8, 239-255. DOI: 10.4098/AT.arch.62-8.

Hirota,T., Hirohata, T., Mashima, H., Satoh, T. \& Obara Y. (2004). Population structure of the large Japanese field mouse, Apodemus speciosus (Rodentia: Muridae), in suburban landscape, based on mitochondrial D-loop sequences. Mol. Ecol., 13, 3275-3282. DOI: 10.1111/j.1365294X.2004.02324.x. 
Jančová, A. \& Baláž I. (2004). The small mammals of selected localitie around Nitra (Žitavská hillock,Tribeč) (in Slovak). Rosalia, 17, 173-180.

Jančová, A., Massányi, P., Nad, P., Koréneková, B., Skalicka, M., Drábeková, J. \& Baláž I. (2006). Accumulation of heavy metals in selected organs of yellow-necked mouse (Apodemus flavicollis). Ekológia (Bratislava), 25(1), 19-26.

Jasińska, K. \& Goszczyński J. (2011). The occurrence of mammals in Warsaw cemeteries. Bydgoszcz: Uniwersytet Technologiczno-Przyrodniczy.

Kalivoda, H., Petrovič, F., Kalivodová, E. \& Kürthy A. (2010). Influence of the landscape structure on the butterfly (Lepidoptera, Hesperioidea and Papilionoidea) and bird (Aves) taxocoenoses in Vel'ké Leváre (SW Slovakia). Ekológia (Bratislava), 29(4), 337-359. DOI: 10.4149/ ekol_2010_04_337.

Klimant, P., Baláž, I. \& Krumpálová Z. (2015). Communities of small mammals (Soricomorpha, Rodentia) in urbanized environment. Biologia, 70 839-845. DOI: 10.1515/biolog-2015-0088.

Klimant, P., Klimantová, A., Baláž, I., Jakab, I., Tulis, F., Rybanský, L., Vadel, L. \& Krumpálová Z. (2017). Small mammals in an urban area: habitat preferences and urban-rural gradient in Nitra city, Slovakia. Pol. J. Ecol., 65, 144-157. DOI: 10.3161/15052249PJE2017.65.1.013.

Kogut, N. \& Padley V.D.A. (1997). Method for reducing mortalities in pitfall traps. Transactions of the Western Section of The Wildlife Society, 33, 7578

Korénková, B., Skalická, M., Drábenková, J. \& Baláž I. (2006). Accumulation of heavy metals in selected organs of yellow-necked mouse (Apodemus flavicollis). Ekológia (Bratislava), 25(1), 19-26. DOI: 10.2478/eko-20200020.

Morello, J., Buzai, G.D., Baxendale, C.A., Rodriguez, A.F., Matteucci, S.D., Godagnone, R.E. \& Casas R.R. (2000). Urbanization and the consumption of fertile land and other ecological changes: thecase of Buenos Aires. Environment and Urbanization, 12, 119-131. DOI $10.1177 / 095624780001200210$

Munshi-South, J. \& Kharchenko K. (2010). Rapid, pervasive genetic differentiation of urban white-footed mouse (Peromyscus leucopus) population in New York City. Mol. Ecol., 19, 4242-4254. DOI: 10.1111/j.1365294X.2010.04816.x
Novák, K., Balát, F., Bartoš, E., Bouček, Z., Daniel, M., Dlabola, J., Doskočil, J., Holman, J., Jagemann, E., Kunst, M., Landa, V., Lang, J., Mařan, J., Miller F., Nosek, J., Novák, K., Obenberger, J., Obr, S., Pelikán, J., Raušer, J., Rosický, B., Rusek, J., Schwarz, J., Skuhravý, V., Slouková, M., Šilhavý, V., Štys, P., Teyrovský, V., Vondráček, K., Zahradník, J. \& Zelenský J. (1969). Methods of collecting and preparing insects (in Czech). Praha: Academia.

Pankakoski, E. (1979). The cone trap - a useful tool for index trapping of small mammals. Ann. Zool. Fenn., 16, 144-150. https://www.jstor.org/ stable/23734422

Pelikán, J., Zejda, J. \& Holišová V. (1977). Efficiency of different traps in catching small mammals. Folia Zool., 26, 1-13.

Pelikán, J., Zejda, J. \& Homolka M. (1983). Mammals in the urban agglomeration of Brno. Acta Scientiarum Naturalium Brno, 17, 1-49.

Riem, J.G., Blair, R.B., Pennington, D.N. \& Solomon D.N. (2012). Estimating mammalian species diversity across an urban gradient. Am. Midl. Nat., 168, 315-332. DOI: 10.1674/0003-0031-168.2.315.

Saito, M. \& Koike F. (2013). Distribution of Wild Mammal Assemblages along an Urban-Rural-Forest Landscape Gradient in Warm-Temperate East Asia. PLoSONE, 8(5), e65464. DOI: 10.1371/journal.pone.0065464.

Shigesada, N. (1980). Spatial distribution of dispersing animals. J. Math. Biol., 9, 85-96. DOI: 10.1007/BF00276037.

Stanko, M., Mošanský, L., Fričová, J. \& Casanova J.C. (1999). Comparison of two sampling methods of small mammals in the margin of a lowland forest. Biológia, 54, 595-597.

Statsoft, Inc. (2004). StatisticaCz, version 7 (in Czech). www.StatSoft.Cz.

TerBraak, C.J.F. \& Šmilauer P. (2012). Canoco reference manual and user'sguide: software for ordination, version 5.0. Ithaca: Microcomputer Power.

Vaniscottea, A., Pleydell, R.J.D., Raoul, F., Quéré, J.P., Jiamind, Q., Wang, Q. Tiaoying, L., Bernarda, N., Coeurdassier, M., Delattre, P., Takahashi, K., Weidmanne, J.CH. \& Giraudouxa P. (2009). Modelling and spatial discrimination of small mammal assemblages: An example from western Sichuan (China). Ecol. Model., 220, 1218-1231. DOI: 10.1016/j.ecolmodel.2009.02.019. 